Article

\title{
Chemical, Physical, and Hydraulic Properties as Affected by One Year of Miscanthus Biochar Interaction with Sandy and Loamy Tropical Soils
}

\author{
Sara de Jesus Duarte ${ }^{1, *(\mathbb{C}}$, Bruno Glaser $^{2}{ }^{(0)}$, Renato Paiva de Lima ${ }^{3}(\mathbb{D})$ and \\ Carlos Eduardo Pelegrino Cerri ${ }^{1}$ (1) \\ 1 Soil and Plant Nutrition, Luiz de Queiroz College of Agriculture, University of São Paulo, Avenida Pádua \\ Dias, 11-Agronomia, Piracicaba, SP 13418-900, Brazil; cepcerri@usp.br \\ 2 Soil Biogeochemistry, Martin Luther University Halle-Wittenberg, Von-Seckendorff-Platz 3, 06120 Halle, \\ Germany; bruno.glaser@landw.uni-halle.de \\ 3 Agricultural Engineering, Federal Rural University of Pernambuco, Rua Dom Manoel de Medeiros, s/n, \\ Dois Irmãos, CEP, Recife, PE 52171-900, Brazil; renato_agro_@hotmail.com \\ * Correspondence: saraduarte@usp.br
}

Received: 21 January 2019; Accepted: 21 March 2019; Published: 29 March 2019

check for updates

\begin{abstract}
Biochar application has improved soil properties contributing to crop growth. This study evaluates the effect of biochar amount on soil physical, chemical and hydraulic properties in sandy (SD) and clay loam (CL) soils under tropical conditions. An incubation experiment was installed under laboratory conditions with eight treatments (control, two kinds of soils, SD and CL, and three biochar doses $\left(6.25,12.5\right.$, and $\left.25 \mathrm{Mg} \mathrm{ha}^{-1}\right)$. Analyses of soil water retention, bulk density (BD), total porosity (TP), pores size, total carbon (TC), and $\mathrm{N}$ were performed after one year. The BD slightly decreased by 0.035 and $0.062 \mathrm{Mg} \mathrm{m}^{-3}$ and TP increased by 1.87 and $2.31 \%$ in CL and SD soil respectively, upon 6.25 to $25 \mathrm{Mg} \mathrm{ha}^{-1}$ biochar application. TC increased in CL and SD by 6.5 and $4.2 \mathrm{~kg} \mathrm{~kg}^{-1}$, respectively, compared to control. The total nitrogen content increased upon biochar addition in CL soil than in SD soil. We found a positive effect of biochar on water availability, microporosity, and a small effect on water retention, especially for CL soil at high biochar application, but this influence did not occur for SD, possibly due to the short time of interaction.
\end{abstract}

Keywords: biochar amount; soil physics; soil fertility; soil water

\section{Introduction}

Traditionally, many approaches have been used to increase the agricultural production, such as the application of fertilizers, organic material, and irrigation. Recently, based on the black earth in the Brazilian Amazon region [1], many researchers have studied biochar and its ecological functions in order to improve soil fertility, soil physical properties, and mitigation of greenhouse gas emissions [2]. Due to these functions, biochar is an attractive tool in agriculture for carbon sequestration and soil quality improvement [3].

Diversified functions in one product are possible because the biochar structure is composed of condensed aromatic groups that give the biochar its black color. Aromatic $\mathrm{C}$ groups in the biochar structure provide stability in soils, which makes biochar a good option for long-term $C$ storage in soils [4]. Biological degradation of biochar leads to partial oxidation of biochar functional groups, resulting in the formation of functional groups on the edges of biochar, causing reactivity in the soil such as nutrient retention and mineral-organic stabilization [4,5]. In addition large porosity and specific surface area, and small density of biochar contribute to increased soil water storage and porosity 
and decreased bulk density of soils, which are particularly important in compacted and degraded soils [6,7].

When biochar is present in a soil system, it can enhance water storage by modifying the portion of the soil pore size distribution associated with aggregation improvements [8]. Water retention is possible because biochar is a porous material and has the potential to absorb and retain large amounts of water [9]. The capability of biochar to retain water is a function of the combination of its porosity and surface functionality. Glaser et al [2] demonstrated that $18 \%$ higher water retention capacity in biochar-amended soils relative to adjacent soils containing low amounts of biochar. Additionally, other soil physical properties can be improved, such as bulk density, porosity, soil aggregation, and soil compaction [10]. These effects may enhance the water availability to crops and decrease soil erosion.

Biochar may not only change soil physical properties but also affect soil chemistry by improving soil fertility and long-term $C$ storage, thus leading to multiple benefits regarding climate change mitigation and adaptation [2]. Due to these beneficial effects, biochar can be used as a soil amendment for improving the quality of agricultural soils [2].

The application of biochar to soils is considered as a win-win strategy to increase soil C sequestration [11]. Biochar is a key component of a potentially sustainable integrated agronomic-biomass-bioenergy production system [11]. Improving soil fertility and soil physical conditions that influence soil hydraulic parameters as water retention $[6,7,12,13]$.

Although there is a wealth of studies concerning the effect of biochar on ecosystem functions [2,14-16], relatively little is known on the effect of biochar on soil physical and hydraulic conditions and the influence of biochar amount. The hypotheses of this paper is that with increase of biochar amount the physical, chemical and hydraulic properties will be improved. The purpose of this paper is to evaluate the effect of biochar amount on the soil physical, chemical, and hydraulic properties of sandy and clay loam soil under tropical conditions.

\section{Material and Methods}

\subsection{Biochar Preparation}

Biochar was commercially produced from agricultural residues of Miscanthus giganteus. This biochar was used because it is a co-product of the production of cellulosic ethanol and has been widely applied because of its increasing availability as a product of the growing biofuels industry. The production of biochar involved drying of the Miscanthus grass at $120-130^{\circ} \mathrm{C}$ in a reactor, followed by pyrolyzation in a second reactor at $450{ }^{\circ} \mathrm{C}$ for about $15 \mathrm{~min}$.

\subsection{Experimental Setup}

The factorial experimental design was completely randomized and comprised the factors biochar rate $\left(0,6.25,12.5\right.$, and $\left.25 \mathrm{Mg} \mathrm{ha}^{-1}\right)$ and soil texture (sand and clay loam), totaling eight different treatments, with four replicates, resulting in a total of 32 pots that were incubated for 12 months at temperatures of $30^{\circ} \mathrm{C}$ under laboratory conditions. Each container was composed of $100 \mathrm{~g}$ of soil and the respective dose of biochar.

\subsection{Sample Preparation, Incubation, and Sampling}

Biochar was incorporated into the soil, based on pre-calculated bulk densities, which included the contribution of the amendments to the final bulk density. The incorporation occurred into a container of $0.5 \mathrm{~L}$ at a rate of $0,6.25,12.5$, and $25 \mathrm{Mg} \mathrm{ha}^{-1}$. The interaction soil-biochar occurred in one year, after this, the soil was sampled. For the sampling, a ring of approximately $7 \mathrm{~cm}^{3}$ was used. The collection of the sample occurred with the insertion of the ring in the soil and the removal of the sample with the advice of aluminum similar to one shovel. 


\subsection{Biochar and Soil Analysis}

\subsubsection{Biochar Analysis}

The elemental analyses as well as $\mathrm{pH}$ and electrical conductivity and yield were performed following the methods recommended by the International Biochar Initiative Guideline [17], labile and stable carbon [18], moisture content [19], volatile matter [20] and ash content [21], and specific surface area [22].

\subsubsection{Fourier Transform-Infrared Spectroscopy (FTIR)}

This analysis was conducted in order to verify absorption bands associated with hydrophobic and hydrophilic groups of biochar. FTIR was used as a suitable tool to visualize and quantify aromatic, carboxylic and phenolic groups at the biochar surface. The biochar was ground until the particle size less than $0.149 \mathrm{~mm}$, the biochar and $\mathrm{KBr}$ were dried $24 \mathrm{~h}$ at $105{ }^{\circ} \mathrm{C}$ and $700{ }^{\circ} \mathrm{C}$, respectively. Sonogel pastilles were prepared at $0.1 \%$ of biochar and $99.9 \%$ of $\mathrm{KBr}$. In this study, a Nicolet Nexus 670 FTIR (Thermo Electron Corporation, Verona Road Madison, WI, USA) was used. All samples were analyzed in transmittance. FTIR imaging mode while collecting all FTIR spectra in the mid-infrared range from 400 to $4000 \mathrm{~cm}^{-1}$, using $4 \mathrm{~cm}^{-1}$ spectral resolution, and 100 scans for each single point collection.

\subsubsection{Hydrophobicity}

Considering that water wets soil material with a $90^{\circ}$ contact angle, we used an index of water repellency (molarity method of ethanol drop MED) proposed by [23]. This procedure employs the concept that a liquid can only completely enter the soil if the theta $(\theta)$ is less than $90^{\circ}$. The procedure evolved drying the biochar in air and putting approximately $2 \mathrm{~g}$ of the sample on the ring (50 $\mathrm{mm}$ $\times 10 \mathrm{~mm}$ ) with the surface of the biochar planed. Solutions of $\mathrm{H}_{2} \mathrm{O}$ :EtOH with $95 \%$ of ethanol were prepared with concentrations of EtOH: 100, 50, 30, 20, 10, and 0. One drop (0.05 mL) of these solutions was applied on the surface of the biochar at a height greater than $5 \mathrm{~mm}$. The time of complete drop penetration in the sample was measured, the temperature at the moment of the test was $25{ }^{\circ} \mathrm{C}$, and the test was repeated with incremented the solution molarity in $1 \%$ until that the drop enters in one time smaller than three seconds. Using one graphic which correlates the percentage of the volume of ethanol that penetrate in the biochar less than three seconds with the surface of tension. We found the surface of tension in each sample and the molarity of the ethanol for each sample [24]. We follow the classification of severity of water repellency where, soils with a MED index $\leq 1$ not water repellent, 2 very low, 3-5 low, 6-8 moderate, 9-10 severe, and 10-12 very severe [24].

\subsubsection{Soil Analyses}

The soils used were Arenosol (sandy texture) and Ferralsol (loamy texture). The soils were sampled at the 0-20 cm layer from two different native vegetation areas located near Anhembi, Brazil $\left(22^{\circ} 43^{\prime} 31.1^{\prime \prime} \mathrm{S}\right.$ and $\left.48^{\circ} 1^{\prime} 20.2^{\prime \prime} \mathrm{W}\right)$ and in Piracicaba, Brazil $\left(22^{\circ} 42^{\prime} 5.1^{\prime \prime} \mathrm{S}\right.$ and $\left.47^{\circ} 37^{\prime} 45.2^{\prime \prime} \mathrm{W}\right)$, both in Sao Paulo state, Brazil. The samples were air-dried, homogenized, and sieved $<2 \mathrm{~mm}$.

Soil chemistry characterization as $\mathrm{pH}$ in calcium chloride $0.01 \mathrm{M}\left(\mathrm{CaCl}_{2}\right), \mathrm{P}, \mathrm{K}, \mathrm{Ca}$, and $\mathrm{Mg}$ in resin, $\mathrm{H}+\mathrm{Al}$ potential acidity $\mathrm{pH}$ SMP; $\mathrm{Al}$ extracted with potassium chloride $(\mathrm{KCl}, 1 \mathrm{M})$, sulfate $\left(\mathrm{S}-\mathrm{SO}_{4}\right)$ extracted with calcium phosphate $\left.\mathrm{Ca}\left(\mathrm{H}_{2} \mathrm{PO}_{4}\right)_{2}, 0,01 \mathrm{M}\right)$, percentage of saturation by bases $(\mathrm{V} \%)$ and percent saturation by aluminum (m\%) [25], C and $\mathrm{N}$ was determined with elemental analyzer [26].

\subsection{Physical Analysis}

\subsubsection{Bulk Density and Particle Density}

The bulk density was determined by the method of [27]. For the determination of particle density (PD) we used approximately one gram of each soil treated with biochar and the control (only soil). 
The soil was placed inside of the instrument and the particle density was determinate using a helium gas pycnometer, model ACCUPYC 1330 (Micrometrics Instrument Corporation, Nacross, GA, USA). The pycnometer determines the volume of solids, by the variation of the pressure of one gas, in a known volume chamber.

\subsubsection{Soil Texture}

Soil texture was analyzed in four replicates, since the maximum dose $\left(25 \mathrm{Mg} \mathrm{ha}^{-1}\right)$ is the one that would be most likely to change the texture of the soil, we tested only that dose and the control treatment (only soil) by the method of [28] that use sodium hexametaphosphate for dispersion. Sand and silt were obtained by wet sieving and clay by sedimentation.

\subsubsection{Porosity}

The total porosity (TP) was calculated from the soil bulk density (BD) and the particle density (PD) [29] using the following equation:

$$
\mathrm{TP}=\frac{\mathrm{PD}-\mathrm{BD}}{\mathrm{BD}} * 100
$$

The macroporosity, mesoporosity, and microporosity were calculated by soil water retention curve using theoretical values for macroporosity superior to $50 \mu \mathrm{m}$, mesoporosity between 15 and $50 \mu \mathrm{m}$, and microporosity less than to $15 \mu \mathrm{m}$ [30].

\subsubsection{Water Retention Curve}

Soil water holding capacity was measured by moisture contents of the samples at different matric potentials $(-15,-10,-3,-1,-0.3,-0.1,-0.06,-0.04$, and -0.02 bar). The points $-15,-10,-3$, $-1,-0.3$, and -0.1 bar in Richard chamber, and $-0.06,-0.04$, and -0.02 bar in Haines' apparatus. Gravimetric analysis was undertaken to determine the moisture contents and these were converted to volumetric basis using the corresponding bulk density values [31] and for the curve was used Van Genuchten type [32].

\subsection{Data Analyses}

Statistical analyses and the graphics were performed using RStudio [33] and the biochar spectrum in the software Origin Lab version 9.1. The data were checked for normality and homogeneity of variances to meet the assumptions of ANOVA and Tukey's test, and a probability of 0.05 .

\section{Results}

\subsection{Soil and Biochar Characterization}

According to Agronomic Institute of Campinas (IAC) and Brazilian Agricultural Research Corporation (Embrapa) the sandy soil has very low amount of $\mathrm{K}$, low of $\mathrm{Mg}$, $\mathrm{P}$, and base saturation $(\mathrm{V} \%)$, medium of $\mathrm{Ca}, \mathrm{S}, \mathrm{Al}, \mathrm{CEC}$, and aluminum saturation $(\mathrm{m} \%)$ and very acidic $\mathrm{pH}$. The loamy soil has a neutral $\mathrm{pH}$, low $\mathrm{Al}$, and $\mathrm{m} \%$, medium $\mathrm{S}$ and $\mathrm{CEC}$, high $\mathrm{V} \%$ and $\mathrm{K}$, and very high $\mathrm{C}$ (Table 1).

Chemical and physical properties of biochar and specific surface area, electric conductivity, $\mathrm{pH}$ and total nitrogen and carbon are given in Table 1 . Biochar has a high quantity of $\mathrm{C}, \mathrm{N}, \mathrm{Ca}, \mathrm{Mg}, \mathrm{Na}, \mathrm{K}$, $\mathrm{P}$, and $\mathrm{S}$ compared to the soil (Table 1).

The FTIR spectrum of the Miscanthus biochar can be recognized in the first main region and the second region. The first region occurs in the interval between 0 and $2000 \mathrm{~cm}^{-1}$ contains individual signals and the second signal in $3685 \mathrm{~cm}^{-1}$ (Figure 1). 
Table 1. Physical and chemical characteristics of biochar Miscanthus, sandy and loamy soil *.

\begin{tabular}{|c|c|c|c|}
\hline Property & Biochar & Sandy Soil & Loamy Soil \\
\hline & \multicolumn{3}{|c|}{$-(\%)$} \\
\hline Sand & & 90 & 40.6 \\
\hline Silt & & 2.2 & 27.7 \\
\hline Clay & & 7.8 & 31.7 \\
\hline $\mathrm{pH}\left(\mathrm{H}_{2} \mathrm{O}\right)$ & \multirow[t]{2}{*}{5.86} & & \\
\hline $\mathrm{pH}\left(\mathrm{CaCl}_{2}\right)$ & & 3.90 & 6.50 \\
\hline \multicolumn{4}{|c|}{ Yield 31} \\
\hline Moisture & 3.5 & & \\
\hline Volatile material & 34.6 & & \\
\hline Ash & 6.1 & & \\
\hline Fixed carbon & 57.1 & & \\
\hline Total N & 0.43 & & \\
\hline${ }^{13} \mathrm{C}$ & -13.41 & & \\
\hline Total C & 66.35 & 0.86 & 1.93 \\
\hline $\mathrm{N}$ & 0.43 & 0.06 & 0.17 \\
\hline $\mathrm{C} / \mathrm{N}$ & 155.4 & 14.3 & 11.4 \\
\hline Labile C (\%) & 2.70 & & \\
\hline Stable C $(\%)$ & 50.87 & & \\
\hline Lability & 0.05 & & \\
\hline $\mathrm{CEC}\left(\mathrm{mmol}_{\mathrm{C}} \mathrm{dm}^{-3}\right)$ & 33 & 69 & 138 \\
\hline Specific surface area $\left(\mathrm{m}^{2} \mathrm{~g}^{-1}\right)$ & 371.9 & & \\
\hline Electric conductivity $\left(\left(\mu \mathrm{S} \mathrm{cm} \mathrm{cm}^{-1}\right)\right.$ & 605 & & \\
\hline \multicolumn{4}{|c|}{$-\left(\mathrm{mg} \mathrm{kg}^{-1}\right)$} \\
\hline $\mathrm{Na}$ & 423 & & \\
\hline $\mathrm{P}$ & 1859 & 4 & 28 \\
\hline$S$ & 634 & 5.30 & 9.50 \\
\hline $\mathrm{Fe}$ & 1317 & & \\
\hline $\mathrm{Mn}$ & 139 & & \\
\hline $\mathrm{Cu}$ & 59 & & \\
\hline Mo & 0.66 & & \\
\hline $\mathrm{Zn}$ & 138 & & \\
\hline $\mathrm{Ni}$ & 7.74 & & \\
\hline \multicolumn{4}{|c|}{$-\left(\mathrm{mmol}_{\mathrm{c}} \mathrm{dm}^{-3}\right)$} \\
\hline $\mathrm{Al}$ & & 5.7 & 0 \\
\hline $\mathrm{H}+\mathrm{Al}$ & & 62 & 18 \\
\hline SB & & 6.9 & 120 \\
\hline $\mathrm{V}(\%)$ & & 10 & 87 \\
\hline $\mathrm{m}(\%)$ & & 45 & 0 \\
\hline
\end{tabular}

* Source: [34]. CEC: cation exchange capacity. $\mathrm{H}+\mathrm{Al}=$ potential acidity, $\mathrm{SB}=$ soma of bases $(\mathrm{Ca}, \mathrm{Mg}, \mathrm{K}), \mathrm{CEC}=$ Cation exchange capacity $(\mathrm{SB}+\mathrm{Al}+\mathrm{H}), \mathrm{V}=$ Base saturation $(\mathrm{SB} \times 100 / \mathrm{CTC}) ; \mathrm{m}=$ Aluminum saturation $(100 \times$ $\left.\mathrm{Al}^{3+} / \mathrm{SB}+\mathrm{Al}^{3+}\right)$.

The first signal in the points 500 can be associated to carbonate (C-O), 860, $894 \mathrm{~cm}^{-1}$ can be attributed to cyclic acid anhydrides (C-C; C-O) group; the second one at 644 and 1095 associated with the band $1030 \mathrm{~cm}^{-1}$ is due to silicon (Si-O), the signal at 1448, 1484, and 1606 can be assigned to carboxylates asymmetric $\left(\mathrm{CO}_{2}\right)$ and at 1700 and 1780 can be attributed to ketones $(\mathrm{C}=\mathrm{O})$ and aromatic carbon, respectively. The second region is due to the presence of silanol (Si-O-H) at $3685 \mathrm{~cm}^{-1}$.

Among these compounds, are hydrophobic: Cyclic acid anhydrides ( $\mathrm{C}-\mathrm{C}$ and $\mathrm{C}-\mathrm{O}$ ) carboxylates asymmetric $\left(\mathrm{CO}_{2}\right)$, ketones aromatic $(\mathrm{C}=\mathrm{O})$, Silicon $(\mathrm{Si}-\mathrm{O})$ and hydrophilic carbonates $(\mathrm{C}-\mathrm{O})$ and silanol (Si-O-H). Although the hydrophilic compounds (silanol and carbonates) have high intensity, the quantity of hydrophobic compounds with high intensity is larger in this biochar (Figure 1). These compounds may contribute to the high hydrophobicity in this biochar, this hydrophobicity 
was verified by analyze of the biochar hydrophobicity in which the result was high hydrophobicity (Figure 2).

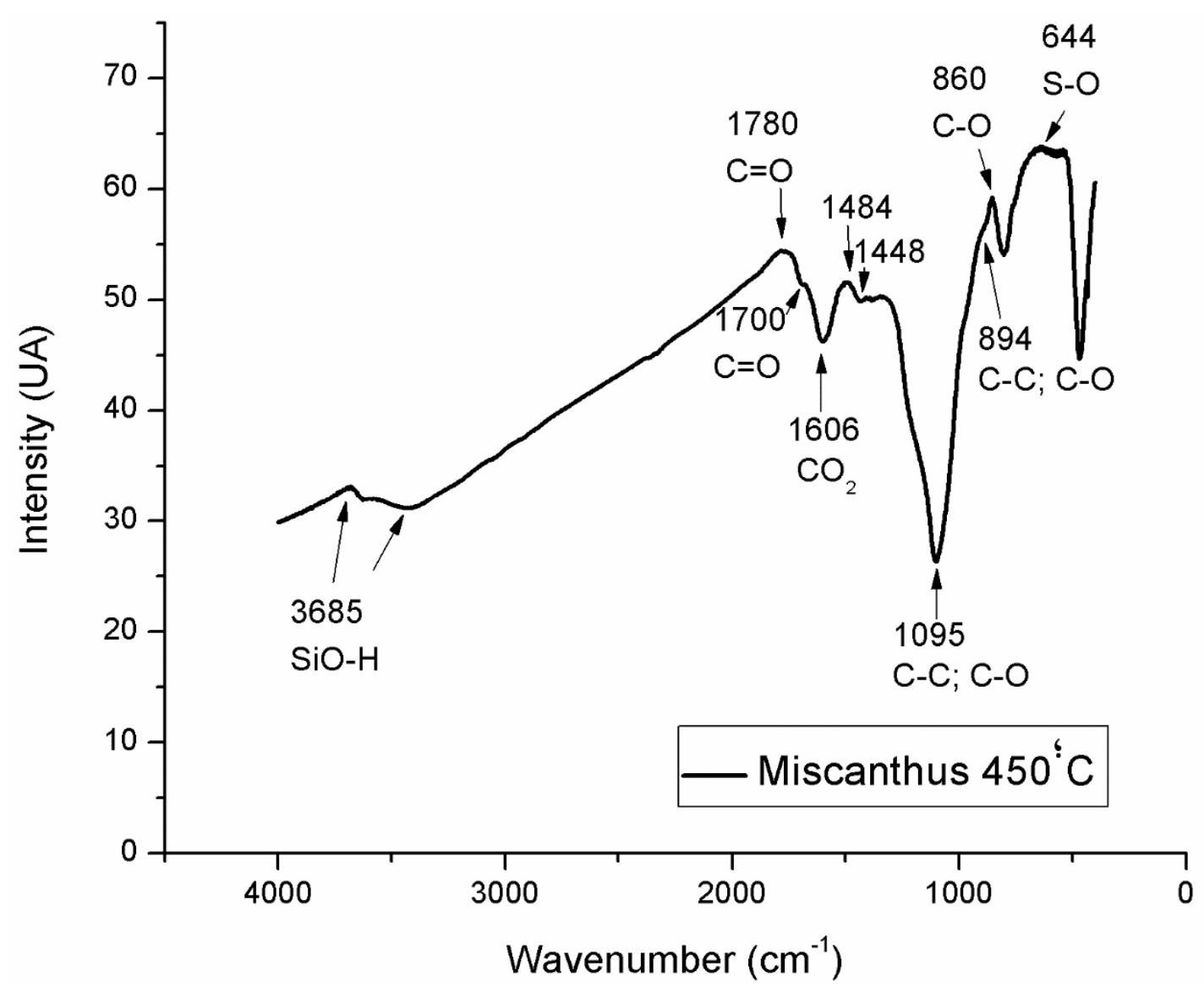

Figure 1. Fourier transform infrared spectrum of Miscanthus biochar pyrolyzed at $450{ }^{\circ} \mathrm{C}$.

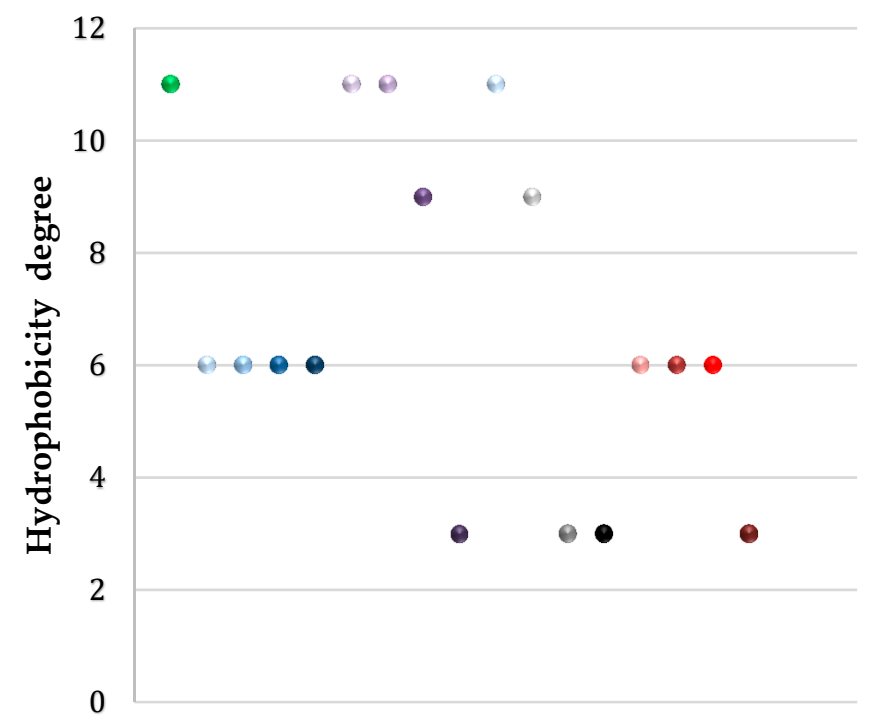

\footnotetext{
- Miscanthus 450

Rice straw 350

• Rice straw 450

- Rice straw 550

- Rice straw 650

- Sawdust 350

- Sawdust 450

- Sawdust 550

- Sawdust 650

- poultry manure 350

• poultry manure 450

- poultry manure 550

- poultry manure 650

- Cane Straw 350

- Cane Straw 450

- Cane Straw 550

- Cane Straw 650
}

Figure 2. Hydrophobicity Miscanthus biochar pyrolyzed at $450{ }^{\circ} \mathrm{C}$ the scale $0-12$ is indicative of degree of hydrophobicity ( $\leq 1$ not water repellent; 2 : Very low; 3-5: Low; 6-8: moderate, 9-10: Severe; 11-12: very severe). 


\subsection{Effect on Soil Chemical Properties}

\subsubsection{Total Carbon}

As expected we found higher amounts of carbon in the loamy soil compared to the sandy soil (Table 1). The total carbon increased with biochar addition in both soils, but for loamy soil, this effect was more accentuated than for sandy soil. In the loamy soil, the total organic $C$ ranged from $23.1 \mathrm{~g}$ $\mathrm{kg}^{-1}$ at the control to $29.6 \mathrm{~g} \mathrm{~kg}^{-1}$ at the highest biochar addition $\left(25 \mathrm{Mg} \mathrm{ha}^{-1}\right)$. This dose increased the amount of carbon by $6.6 \mathrm{~g} \mathrm{~kg}^{-1}$ in loamy soil (Figure 3A). For the sandy soil, the total organic $\mathrm{C}$ ranged from $5.7 \mathrm{~g} \mathrm{~kg}^{-1}$ at the control treatment to $10 \mathrm{~g} \mathrm{~kg}^{-1}$ at $25 \mathrm{Mg} \mathrm{ha}^{-1}$ of biochar addition from the soil. Therefore, this increase was of $4.2 \mathrm{~g} \mathrm{~kg}^{-1}$.
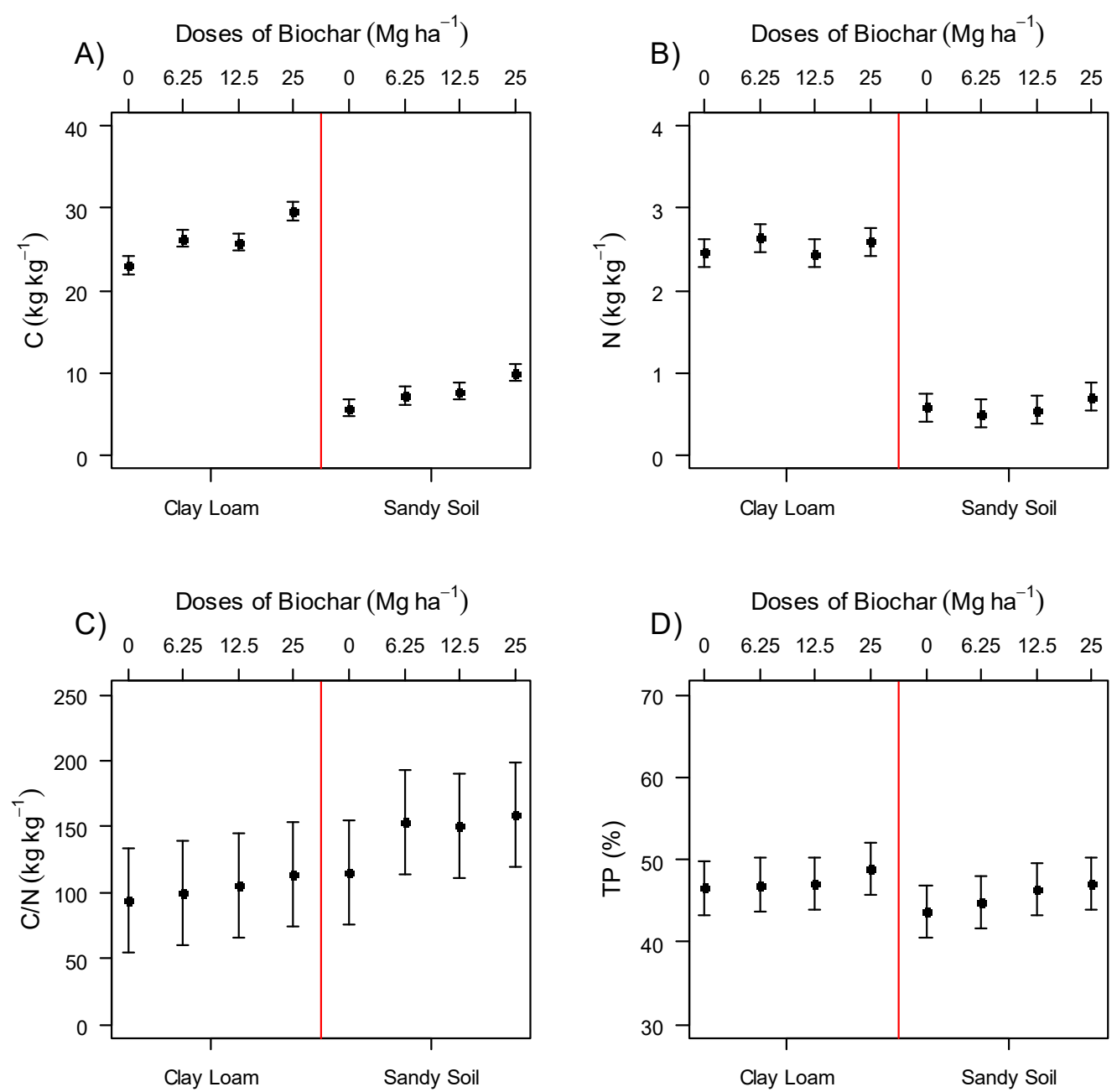

Figure 3. Cont. 


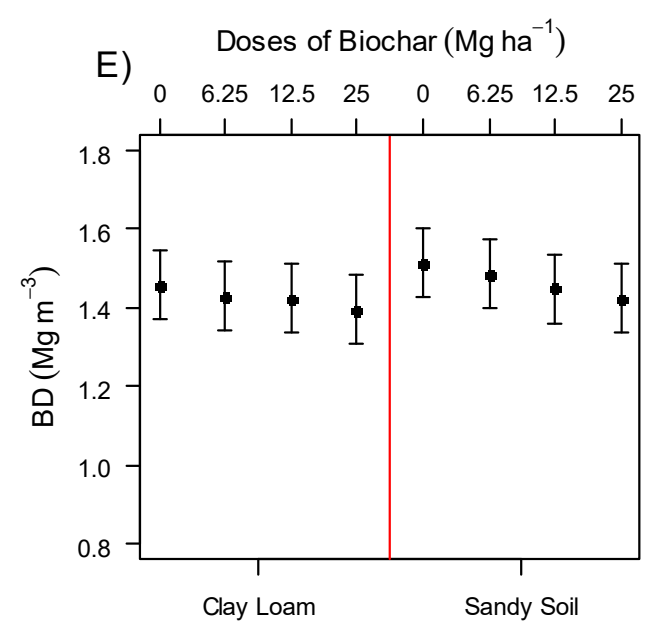

Figure 3. Effect of biochar amount on soil physical and chemical properties in clay loam and sandy soil. C: carbon; N: nitrogen; C/N: atomic ratio; TP: total porosity; BD: bulk density. (A) Carbon content;

(B) Nitrogen content; (C) Carbon and Nitrogen ratio; (D) Total porosity; (E) Bulk density.

\subsubsection{Total Nitrogen}

Total N (TN) content ranged between $2.4 \mathrm{~g} \mathrm{~kg}^{-1}$ and $2.6 \mathrm{~g} \mathrm{~kg}^{-1}$ for the loamy soil and between 0.58 and $0.70 \mathrm{~g} \mathrm{~kg}^{-1}$ for sandy soil. (Figure 3B). The increasing amount of biochar application tended to increase soil TN contents compared to the control, but this difference was not statistically significant $(p>0.05)$.

\subsubsection{C:N Ratio}

For the loamy soil the $\mathrm{C} / \mathrm{N}$ ratio ranged between 9.4 (control) and 11.4 (25 $\mathrm{Mg} \mathrm{ha}^{-1}$ of biochar; Figure 3C); for the sandy soil, C/N ratio ranged between 11.6 (control) and 15.9 (25 Mg ha ${ }^{-1}$ of biochar; Figure $3 \mathrm{C}$ ). Increasing biochar amounts increased the $\mathrm{C} / \mathrm{N}$ ratio, but this increase was not statistically significant $(p<0.05)$.

\subsection{Effect on Soil Physical Properties}

\subsubsection{Porosity}

The biochar amount increased the porosity in both soils. Although the difference is not significant is possible to note that in both soils the biochar amount increased the total porosity. Compared to the control treatment in the loamy soil, the $25 \mathrm{Mg}$ biochar ha ${ }^{-1}$ increased the porosity from 47 to $49 \%$ and for sandy soil from 44 to $47 \%$ (Figure 3D).

\subsubsection{Bulk Density}

There is no significant difference $(p>0.05)$ between loamy and sandy soil and biochar doses on bulk density. In both soils, the total bulk density decreased with increasing of biochar, but for sandy soil, this effect was more accentuated than for loamy soil. In the loamy soil, the bulk density ranged from $1.46 \mathrm{~g} \mathrm{~cm}^{-3}$ at the control to $1.39 \mathrm{~g} \mathrm{~cm}^{-3}$ in $25 \mathrm{Mg} \mathrm{ha}^{-1}$ (Figure 3E) and for sandy soil between $1.51 \mathrm{~g} \mathrm{~cm}^{-3}$ (control) and $1.42 \mathrm{~g} \mathrm{~cm}^{-3}\left(25 \mathrm{Mg} \mathrm{ha}^{-1}\right)$.

\subsubsection{Texture}

The biochar addition did not change the soil texture in both sandy and clay loam soil, even when applied $25 \mathrm{Mg} \mathrm{ha}^{-1}$ of biochar (Table 2). 
Table 2. Influence of biochar amount on soil texture in sandy and clay loam soil.

\begin{tabular}{|c|c|c|c|c|}
\hline Treatment & Sand & Silt & Clay & Textural Class \\
\hline \multicolumn{5}{|c|}{$\longrightarrow(\%) \longrightarrow$} \\
\hline Control & 40.6 & 27.7 & 31.7 & Clay Loam \\
\hline Biochar $25 \mathrm{Mg} \mathrm{ha}^{-1}$ & 34.7 & 27.0 & 38.3 & Clay Loam \\
\hline Control & 90 & 2.2 & 7.8 & Sandy \\
\hline Biochar $25 \mathrm{Mg} \mathrm{ha}^{-1}$ & 91 & 5.8 & 3.3 & Sandy \\
\hline
\end{tabular}

\subsection{Effect on Soil Hydraulic Properties}

\subsubsection{Water Retention Curve}

In the loamy soil at low biochar doses $\left(6.25\right.$ and $\left.12.5 \mathrm{Mg} \mathrm{ha}^{-1}\right)$, low tension was enough to reduce the water content of the macropores. However, in control treatment, this decrease occurred from $100 \mathrm{hPa}$ and, for the highest biochar amount $\left(25 \mathrm{Mg} \mathrm{ha}^{-1}\right)$, was necessarily approximately $1000 \mathrm{hPa}$, for the decrease the water content. We checked that the higher biochar amount increased the water retention and was higher than the other treatments up to $1000 \mathrm{hPa}$ and from that potential water retention was similar for all treatments (Figure 4a).
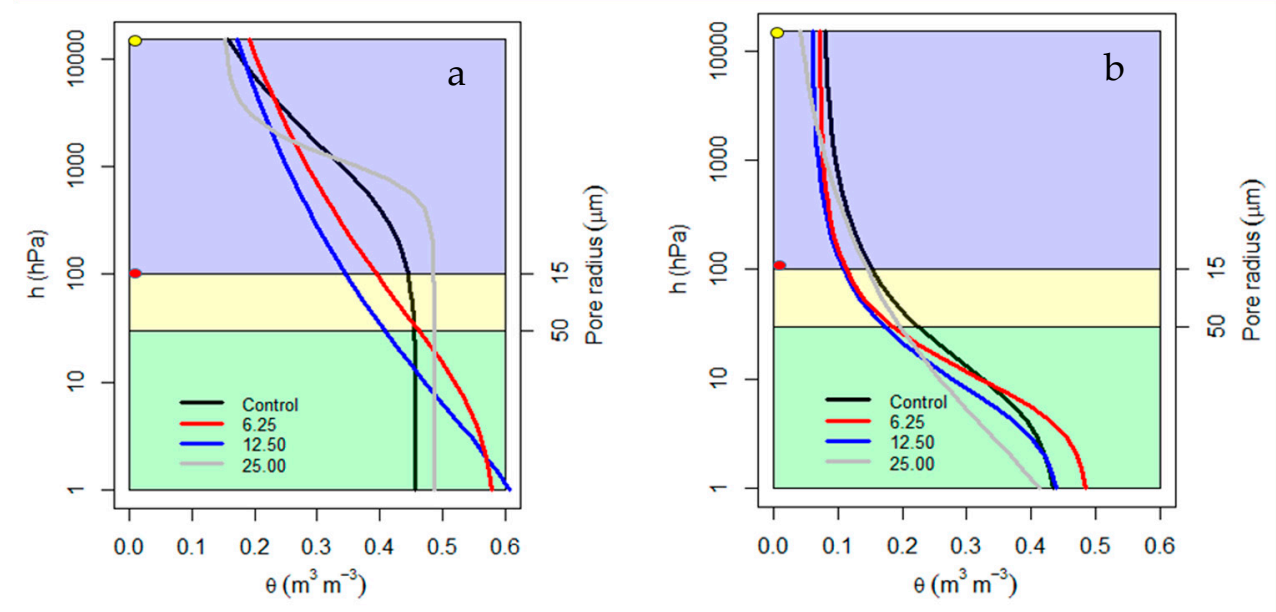

- Field capacity (FC); $\bigcirc$ Wilting point (WP), $\mathrm{FC}$-WP*BD= Water available content; $\|$ Micropores $(<15 \mu m)$-Water retention; Mesopore (15-50 $\mu \mathrm{m})$-Conduction of water after drainage; ${ }^{-}$Macropore ( $\left.>50 \mu \mathrm{m}\right)$ - Drainage and aeration.

Figure 4. Effect of biochar amount on soil water retention in clay loam and sandy soil. (a) Clay loam soil; (b) Sandy soil.

The biochar amount did not affect the water retention in sandy soil, little increase in the soil water retention in low potential $(1-10 \mathrm{hPa})$ was checked in $12.5 \mathrm{Mg} \mathrm{ha}^{-1}$. From of potential $(10 \mathrm{hPa})$, the biochar dose did not affect the soil water retention, the curve behavior was similar in all treatments and the difference between the treatments in the water retention was very little and insignificant (Figure $4 b$ ).

\subsubsection{Plant-Available Water Content}

Comparing loamy and sandy soil, the clay loam soil has higher water available content than the sandy soil. In clay Loam soil and sandy soil the higher biochar dose increased the water available content compared to control treatment in $0.05 \mathrm{~cm}^{3} \mathrm{~cm}^{3}$ in clay loam and $0.03 \mathrm{~cm}^{3}$ of water per $\mathrm{cm}^{3}$ of soil in sandy soil (Figure 5). 


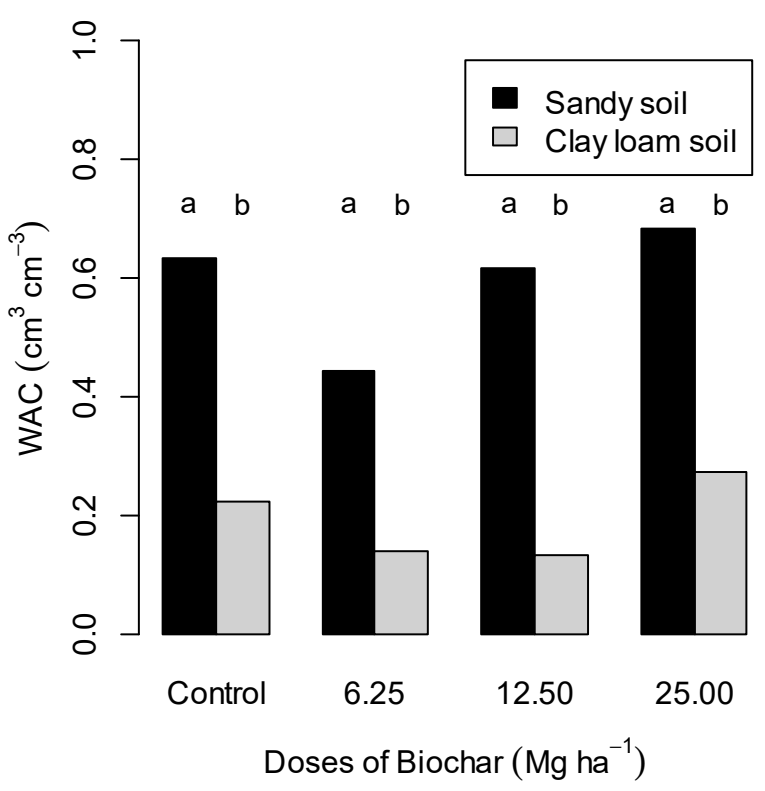

Figure 5. Effect of biochar doses on plant-available water content in clay loam and sandy soil. AWC Plant available water content.

3.4.3. Effect of Biochar Doses on Pore Size Distribution and Its Relation with the Water Retention Curve

Biochar application not only increased the total porosity but also alters soil pore size distribution and water retention. The biochar doses affected the macroporosity, mesoporosity, and microporosity in both soils, the changes in the porosity altered the behavior in the water retention curve for both soil and in all treatments (Figure 6).

In the loamy soil, in the treatments control and $25 \mathrm{Mg} \mathrm{ha}^{-1}$, the total porosity was approximately 48 and $49 \%$ respectively. The very low quantity of macropores kept the same behavior in the curve. The variation occurred only in the microporosity range from $100 \mathrm{hPa}$, the high water retention in these treatments could be attributed to microporosity in the control and $25 \mathrm{Mg}^{-1}$ of biochar. Different behavior in the water retention curve occurred for 6.25 and $12.5 \mathrm{Mg} \mathrm{ha}^{-1}$ of biochar; the macroporosity was higher compared to other treatments. In the $6.25 \mathrm{Mg} \mathrm{ha}^{-1}$ dose, $61 \%$ of the pores comprised approximately 38\% of macropores, $9 \%$ mesopores, and 53\% micropores, and the high quantity of macropores was responsible for the high drainage of water at a low potential. In the $12.5 \mathrm{Mg} \mathrm{ha}^{-1}$ dose, $59 \%$ of the total porosity comprised $21 \%$ of macropores, $12 \%$ mesopores, and $67 \%$ micropores.

The intermediate doses of biochar (6.25 and $\left.12.5 \mathrm{Mg} \mathrm{ha}^{-1}\right)$ increased the macroporosity and mesoporosity and decreased the microporosity. This porosity affected the curve in low potential. From $100 \mathrm{hPa}$, the field capacity increases the water retention with an increase of the tension in all treatments of the clay loam soil (Figure 6).

In sandy soil, the macroporosity was high in all treatments. This macroporosity contributed to high drainage at low matric potential, up to $100 \mathrm{hPa}$ the low quantity of micropores promoted little changed in the water retention curve. In control treatment, $44 \%$ of the pores was controlled by macroporosity, $17 \%$ by mesopores, and $35 \%$ by micropores. In the 6.25 and $12.5 \mathrm{Mg}$ ha $^{-1}$ doses, the volume of approximately $24 \%$ of micropores contributed to the low variation in the water content when increased the potential. The addition of $25 \mathrm{Mg} \mathrm{ha}^{-1}$ of biochar increased the microporosity to approximately $30 \%$ (Figure 6). 

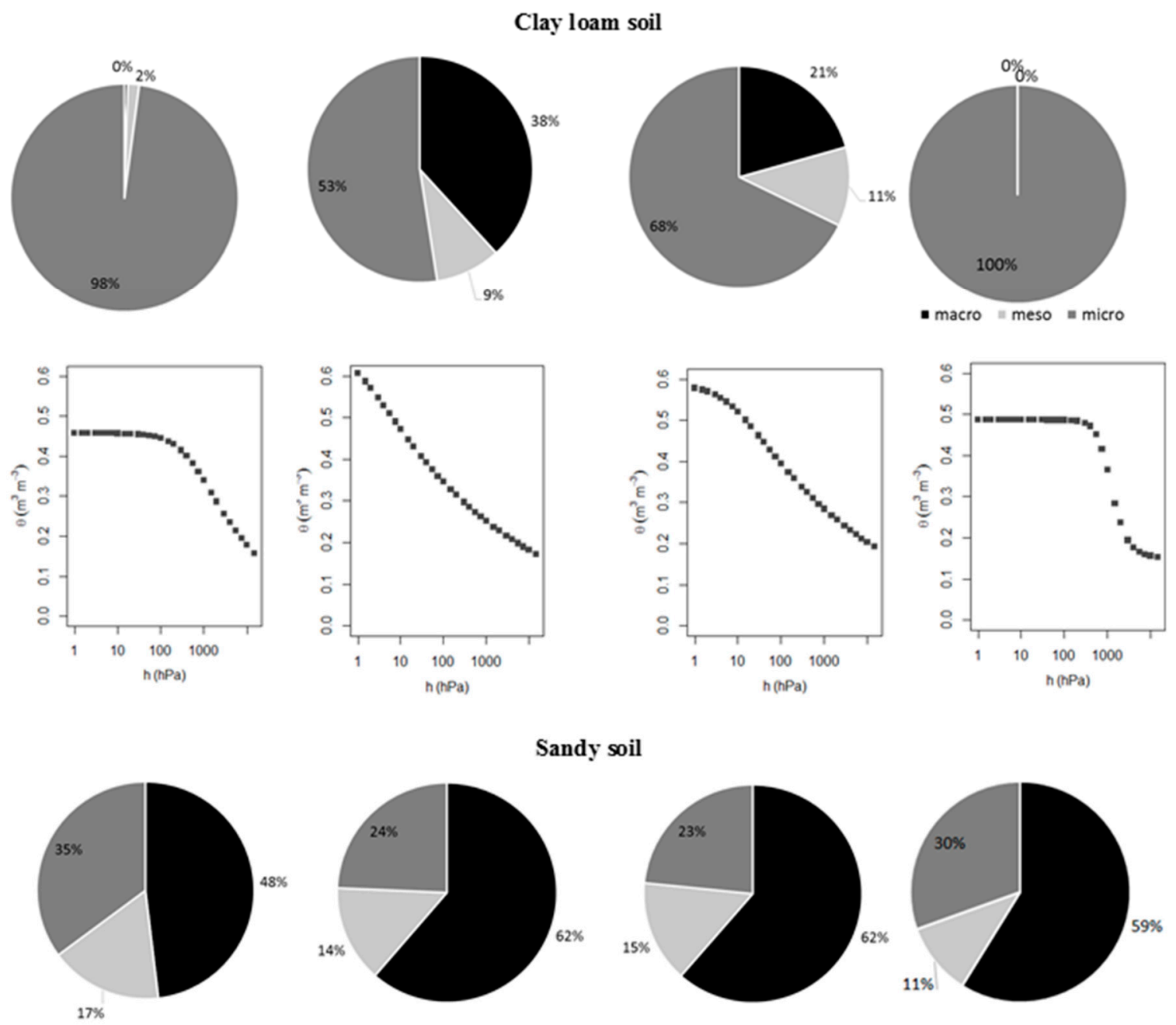

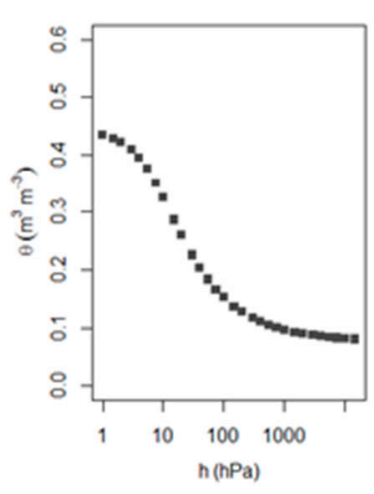

Control

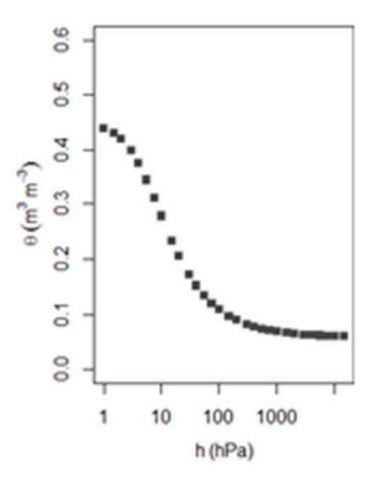

Biochar 6.25 $\mathrm{Mg} \mathrm{ha}^{-1}$

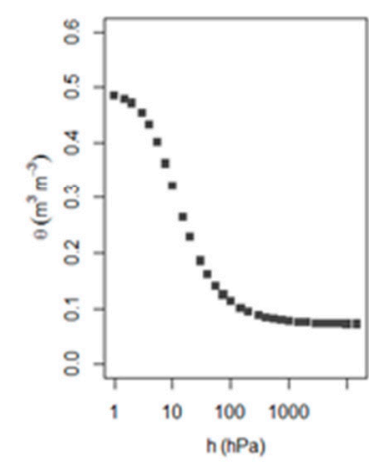

Biochar 12.5 $\mathrm{Mg} \mathrm{ha}^{-1}$

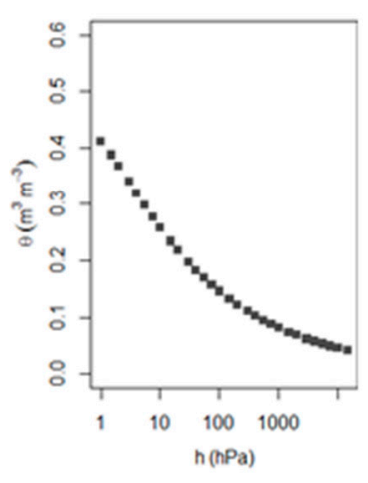

Biochar $25 \mathrm{Mg} \mathrm{ha}^{-1}$

Figure 6. Effect of biochar amount on macropores ( $>50 \mu \mathrm{m})$; mesopores $(15-50 \mu \mathrm{m})$ and micropores $(<15 \mu \mathrm{m})$, and its relation with water retention.

\section{Discussion}

During temporal biochar exposure to the environment, hydrophobic moieties such as polycondensed aromatic moieties decrease while hydrophilic functional groups such as carboxylic acids increase [2,5]. 
Both soils have low fertility but the added biochar has high fertility (Table 1). Therefore, biochar has a direct positive effect of the investigated tropical soils. It was already stated by [2] that a potential fertilization effect of biochar is high. Laird at al [14] observed significant increases in plant-available P, $\mathrm{K}, \mathrm{Ca}$, and $\mathrm{Mn}$ upon 5 and $10 \mathrm{Mg} \mathrm{ha}^{-1}$ biochar addition to the soil after 500 days. This increase was attributed to the presence of these nutrients in the biochar itself that over the time can be available in the soil. Because of chemical and biological biochar stability, the biochar is less reactive in soil than other organic molecules the biochar degradation requires a long time. The study of [35] revealed a biochar degradation of $25 \%$ within 100 years, translated into a biochar turnover of around 300 years.

\subsection{Biochar Effects on Soil Nutrient Storage Capacity}

\subsubsection{Total Carbon}

The addition of $25 \mathrm{Mg} \mathrm{ha}^{-1}$ of biochar increased the total carbon in both soils but this difference was significant only for clay loam soil compared to lower doses and the control. A similar result in clay loam soil was verified by [15] after one year of interaction (Figure 3A). Similarity, [14] verified that the addition of biochar to the loamy soil increased the total $C$ content after the 500 days incubation by 17.6, 37.6, and $68.8 \%$, respectively, for the 5,10 , and $20 \mathrm{~g} \mathrm{~kg}^{-1}$ biochar treatments in relation to control treatment (only soil).

Sandy soil has a tendency to increase carbon content with biochar addition (6.25 to $\left.25 \mathrm{Mg} \mathrm{ha}^{-1}\right)$, but this difference was not significant (Figure 3A). Liu et al [6] reported a three-fold increase of soil organic carbon upon $20 \mathrm{Mg} \mathrm{ha}^{-1}$ biochar addition to sandy soil. Weber et al [36] reported higher C and $\mathrm{N}$ contents three years after compost with biochar application from municipal waste in the range of 30 to $120 \mathrm{Mg} \mathrm{ha}^{-1}$ at a field trial with Dystric Cambisol.

The increase of carbon concentration of $6.6 \mathrm{~kg} \mathrm{~kg}^{-1}$ in the loamy soil and $4.2 \mathrm{~kg} \mathrm{~kg}^{-1}$ in sandy soil with addition of $25 \mathrm{Mg} \mathrm{ha}^{-1}$ (Figure 3A) can contribute for increase of aggregation stability, water retention, water available content, and reduction of soil bulk density, these soil physical properties are essential for the soil physical quality and, therefore, for plant development.

\subsubsection{Nitrogen}

Increase in the quantity of nitrogen with an increase of the biochar doses was also verified by $[2,15]$ in clay loam soil. As well as we found in this experiment, that occurred increase but the difference was not significant with one year of interaction, [12] verified that the difference was not significant in the first year of soil-biochar interaction.

The time required for the increase of the nitrogen in the soil with biochar addition can be attributed to the $\mathrm{N}$ in the biochar is present in a stable form [14]. Therefore, the increase of 0.2 and $0.12 \mathrm{~g} \mathrm{Kg}^{-1}$ for loamy and sandy soil respectively (Figure 3B), can increase with the time of interaction. The increase of nitrogen amount in the soil is essential for the plant productivity, the biochar addition can increase the amount of nitrogen in the soil without the need of the farmer spend a lot of money with fertilizers.

\subsubsection{C:N Ratio}

Independent of biochar amount, the loamy soil has lower C:N ratio compared to sandy soil, which can be attributed to the high quantity of nitrogen in clay loam soil, the increase in the biochar dose increased the C:N ratio, for sandy soil, increased $4.3 \%$ and for clay loam soil $2 \%$. This increase can be attributed to the high quantity of carbon in biochar (Figure 3C). As well, in this article, Zhang et al [15] verified that the high amount of biochar amendment of $40 \mathrm{Mg} \mathrm{ha}^{-1}$ induced a high C:N ratio 14-16 under $40 \mathrm{Mg} \mathrm{ha}^{-1}$ as compared to 13 under $20 \mathrm{Mg} \mathrm{ha}^{-1}$. The low increase in the C:N ratio can be associated with low dose in both soils. The increase in the $\mathrm{C}: \mathrm{N}$ ratio decreased the decomposition of the material if the C:N ratio is superior to 35, the decomposition is low, in every treatment the C:N ratio was inferior to 21 , indicated that we do not have problems with decomposition and nitrogen immobilization [37]. 


\subsection{Biochar Effects on Soil Physical Properties}

\subsubsection{Total Porosity}

Similar to our results, many studies have proved that biochar addition increased the porosity in clay loam and sandy soil [7]. The increase of the porosity with an increase of biochar amount occurred because the biochar is a material with high total porosity, composed by approximately $80 \%$ of pore volume, with normally, $95 \%$ of these pores are less than a $20 \mathrm{~nm}$ of diameter [38], when the biochar is putted in the soil the total porosity increase (Figure 3D). The high porosity in biochar can be a strategy for increasing the porosity, aeration and water movement, water holding capacity, heat and gases in degraded soils, and with compaction problems [12]. The alteration in the porosity of the soil is reflected in the bulk density, but it is important to consider that the low bulk density and high total porosity may not be always beneficial for plant growth, because of slight compaction can improve root-soil contact and pore connectivity, allowing higher nutrient and water transport and supply to plant roots [39].

\subsubsection{Bulk Density}

Biochar addition to soil reduced the bulk density even at low amount (Figure 3e), in a few cases, biochar application at rates $<10 \mathrm{Mg} \mathrm{ha}^{-1}$ [40] may not reduce bulk density. However, in most research even in small quantities biochar reduces bulk density, and with increase the biochar amount the decrease in the bulk density is more expressive [12,41-43]. Omondi et al [7] reviewed studies on biochar and soil bulk density prior to 2016, and found that the biochar application reduced bulk density by $3-31 \%$ in 19 out of 22 studies, indicating that bulk density generally decreases with biochar application.

The magnitude of the biochar effect on bulk density can be explained by simple dilution of the soil with the low bulk density of the biochar [14]. This is so important for the reduction of bulk density and increases soil porosity that contributes directly to the plant development. Similar to this result (Figure 3e), Blanco-Canqui [12] found that the effect of biochar on a reduction of bulk density on clayey soils can be smaller than sandy soil, because of larger differences in size and density between biochar and sand particles being larger than those between biochar and clay particles. The biochar could also reduce bulk density in the long term by interacting with soil particles and improving aggregation and porosity favoring the water retention and availability of water for the plants and promoting a suitable means for the plant development [12]. These results proved that in clay loam and sandy soil the farmers can use biochar for improve the soil physical properties such as bulk density and porosity, properties necessary for the increase the soil quality and consequently plant productivity.

\subsubsection{Texture}

Our results suggest that in clay loam and sandy soil, biochar addition up to $25 \mathrm{Mg} \mathrm{ha}^{-1}$ did not modify soil texture. Similarly, Githinji [43] found the same result up to $25 \mathrm{Mg} \mathrm{ha}^{-1}$, but with $50 \mathrm{Mg}$ $\mathrm{ha}^{-1}$ he verified that the soil texture shifted slightly from 'loamy sand' to 'sand'. This can occur due to the presence of many larger particles in the range of sand in the biochar.

\subsection{Biochar Effects on Soil Hydraulic Properties}

\subsubsection{Water Holding Capacity}

The fact that the biochar has been produced from Si-enriched raw feedstock (Figure 1), can increase the water retention in the soil because the Si reacts with water molecules in polymerizations reactions causing phytolith or silica hydrogel formations, which are essential structures used in plant biochemical and biophysical reactions [44]. The result is that the biochar may express the same tendency to react with soil water by physically adhering water molecules or trapping water vapor in internal pores [45]. Soon, assuming that water-binding pathways of Si-enriched biochar operate in 
soils, the Si content of biochar may be an important characteristic to improve soil-water storage, and therefore, the feedstock switchgrass can be used for improving the soil water retention [12]. Though the hydrophobicity in this biochar can contribute to the reduction of the efficiency in the improvement of soil water retention, the contact with water by means of the saturation process for the production of the retention curve and the maintenance of the field capacity of the samples during one year of soil-biochar interaction can reduce this hydrophobicity. Kinney [46] affirmed that the exposition of the biochar in water can reduce its hydrophobicity.

Considering that the biochar is hydrophobic when the contact angle is higher than $90^{\circ}$ [47] observed a $69.5 \%$ decrease of the contact angle of biochar after one year of its addition to soil suggesting that initial biochar hydrophobicity disappeared within one year. This decrease in hydrophobicity will improve soil water retention [46]. Based on these results it is possible that the hydrophobicity of this biochar used in this experiment was not a negative factor for water retention.

The effect of biochar on water retention is dependent on soil texture [48]. In the loamy soil, the water retention at low doses $\left(6.25\right.$ and $\left.12.5 \mathrm{Mg} \mathrm{ha}^{-1}\right)$ of biochar was smaller than the treatment with no addition of biochar (Figure 4). Two reasons can explain this behavior. The first one is that smaller biochar doses inferior to $20 \mathrm{Mg} \mathrm{ha}^{-1}$ have no effect in the water retention [49] or can reduce the water retention because of fine-textured soils may be less responsible to biochar application and larger amounts of biochar may be needed to increase water retention which can result in increased plant available water [12]. Medium $\left(20 \mathrm{Mg} \mathrm{ha}^{-1}\right)$ and high $\left(100 \mathrm{Mg} \mathrm{ha}^{-1}\right)$ biochar applications can improve water-holding capacity as verified by [50]. The second reason is that in those doses $(6.25$ and $12.5 \mathrm{Mg}$ $\mathrm{ha}^{-1}$ ) the organic material was higher and differed from the control treatment. Peake et al [50] affirmed that soils rich in organic material responded less or not to biochar amendment. Devereux Devereux et al [42] showed that an increase in biochar amount results in an increase in soil water content for a given matric potential, suggesting that as matric potential increases, biochar retains more water within pores as compared to biochar-free sandy loam soil.

The high water retention at $25 \mathrm{Mg} \mathrm{ha}^{-1}$ of biochar can be explained by the high dose applied also the high specific surface area in biochar (Figure 4) that associated to the high the electric conductivity can contribute for increasing the water retention in biochar and consequently increase the soil water storage. Blanco-Canqui [12] found in the literature review that the biochar increases the ability of the soil to retain water in $90 \%$ of cases but the large amounts of biochar can be required to increase water retention consistently. Finally, in the control treatment, the high microporosity can be associated with high soil bulk density (Figure 3e), which can contribute for the increase in water retention in this treatment.

In sandy soil, with pour organic material, we not verified improvement in the soil water retention, the no effect of biochar on the soil can be attributed to the biochar that was applied alone. Laird et al [14] and Christensen [51] verified that the biochar has no effect in sandy soil if applied alone and suggest the application with organic compost and the incorporation of biochar in the subsoil. Another reason is that the increase of soil water retention can occur in coarse texture soil or soils with a large number of macropores if large amounts of biochar are applied [52]. Gaskin et al [53] reported improvements in soil-moisture storage after biochar was added at high rates $\left(88 \mathrm{Mg} \mathrm{ha}^{-1}\right)$ in Ultisol with a coarse texture. In addition, the time of interaction, Salinas et al [54] verified that for increasing the water holding capacity of soils is required a longer period. However, Liu et al [6] reported a two-fold increase of plant-available water holding capacity upon $20 \mathrm{Mg}$ biochar ha ${ }^{-1}$ plus $30 \mathrm{Mg} \mathrm{ha}^{-1}$ compost addition to a sandy soil when combined with $30 \mathrm{Mg} \mathrm{ha}^{-1}$ compost addition alone.

In the loamy soil, the farmers can use the biochar in the dose $25 \mathrm{Mg} \mathrm{ha}^{-1}$ for increase the soil water retention and in sandy soil the same dose is necessary, however, to obtain one good increase in the soil water retention is necessary more than one year of interaction soil-biochar. The increase in the retention of the water is essential for agriculture, ambient and plant productivity. With more water in the soil, the farmers can reduce the frequency of irrigation, reducing the use of water so necessary for the environment. In areas of familiar agriculture that do not use irrigation, the biochar can be used 
for provided water in a period drought. With a continuous supply of water to the plants, production tends to grow significantly.

\subsubsection{Relation between Water and Pore Size Distribution}

We found that the biochar application with different particle size changes the soil pore size distribution. This occurred due to intrapores (pores inside biochar particles), most of them having diameters $<1 \mu \mathrm{m}$ (micropores), and the different biochar particle size change the pore space between biochar particles and soil (interpores). The contribution with interpores and intrapores create heterogeneity in pore size distribution, as verified in our results in clay loam and sandy soil. In clay loam soil, intermediate doses $\left(6.25\right.$ and $\left.12.5 \mathrm{Mg} \mathrm{ha}^{-1}\right)$, increased the macroporosity and mesoporosity and decreased the microporosity, for the control and $25 \mathrm{Mg} \mathrm{ha}^{-1}$ the total porosity was dominated by micropores. However, in sandy soil, the macroporosity was high in all treatments, the mesoporosity increased with increase of biochar amount but the microporosity decrease (Figure 6).

The low amount of biochar $\left(6.25\right.$ and $\left.12.5 \mathrm{Mg} \mathrm{ha}^{-1}\right)$ contributed to increase the macroporosity as verified by Gaskin et al [55]. In sandy soil, similar results were found by [56] who verified that biochar addition increased macropores between $5 \%$ and $20 \%$. The increase of macropores $(>50 \mu \mathrm{m})$ contribute to drainage and aeration of the soil and heat flow [12,48], and the drainage corresponds to decreasing values of water retention and do not hold available water for the plants [56,57] but increases the soil aeration contributing for aerobic microorganisms and plant respiration and the heat flow contributes to warming the soil and the atmosphere near to the soil.

In clay loam soil the mesopores increase only in intermediate doses $\left(6.25\right.$ and $12.5 \mathrm{Mg} \mathrm{ha}^{-1}$ and decrease in $25 \mathrm{Mg} \mathrm{ha}^{-1}$. In sandy soil, only in the high amount $25 \mathrm{Mg} \mathrm{ha}^{-1}$ reduced the mesoporosity. The increase in the mesoporosity pores with a diameter between $15-50 \mu \mathrm{m}$ is important because contribute to conduction of the water in the soil during the water distribution process that occurs after the infiltration, when the macropores are emptied [58].

We found mainly micropores in clay loam soil, at the control treatment and in $25 \mathrm{Mg} \mathrm{ha}^{-1}$. The high microporosity, can be associated to high density in the control and high biochar amount in $25 \mathrm{Mg} \mathrm{ha}^{-1}$. Due to high microporosity the water retention was high compared to smaller doses (6.25 and $12.5 \mathrm{Mg} \mathrm{ha}^{-1}$ ). Studies have found that biochar can reduce the proportion of drainable pores and increase the quantity of mesopores and micropores (Petersen et al., 2016). The fact that biochar application contribute with pores inside particles (intrapores) less than $1 \mu \mathrm{m}$ is favorable for the water retention in the soil when matric potential is lower than $-165 \mathrm{hPa}$ [58] can explain why only loamy soil with $25 \mathrm{Mg}$ biochar ha ${ }^{-1}$ retained high quantity of water after $-165 \mathrm{hPa}$. However, biochar with a high quantity of pores between biochar particle and soil (intraporosity) is more effective in the water retention at lower soil water potential, these interpores control water retention when soil water potential $(\psi)$ is less than $-16.5 \mathrm{kPa}[58]$.

The micropores, besides the water retention, increase the plant-available and nutrient storage $[59,60]$. Cation retention was observed when mixing soil with biochar [2] However, the underlying mechanism for this observation is still unclear. However, the nutrient retention mechanisms, such as pores, surface adsorption, cationic and anionic interaction, are determined by the physical and chemical structure of biochar $[2,59,60]$.

Water availability, storage, and nutrient are crucial for plant productivity. Biochar has the potential to alter soil hydrology and to drive shifts for water stored in soils and increase plant-available water under dry conditions $[59,61]$. Instead, it would provide more storage of water on the landscape under wet conditions [61]. However, the low quantity of biochar can be favorable for water flow, aeration, soil water retention and water available content for the plants [12,43].

\subsubsection{Plant-Available Water Content}

Similar to this paper, Tryon [61] reported that application of biochar increased plant-available water content in sandy soil and no effect in a loamy soil. Similarly, Blanco- Caqui [12] found that 
biochar application consistently increased plant available water in 21 out of the 29 soils, suggesting that plant-available water increased when biochar was applied in $72 \%$ of cases such a response may be attributed to the high microporosity of the biochar. Due to the soil moisture, retention may only be improved in coarse-textured soils, a careful choice of biochar/soil combination needs to be taken into consideration.

The increase in plant-available water with biochar suggests that the application of biochar to croplands could contribute to the reduction of the frequency of irrigation. This can be particularly important in water-limited or semiarid regions [2,6].

\subsubsection{Implications for Farmers in Brazil}

It is clear from the present study that high rate of biochar $\left(25 \mathrm{Mg} \mathrm{ha}^{-1}\right)$ in clay loam soil can be beneficial for the chemical and physical properties (e.g., $\mathrm{C}$ and $\mathrm{N}$ concentrations, $\mathrm{C} / \mathrm{N}$ ratio, plant available water, porosity, and bulk density) improving the soil water content, reduce plant water stress and increase the amount of $C$ and N. However, the good results in the improvement in soil physical and chemical especially in sandy soil, can be associated with time of interaction because the biochar is a stable material [55]. The Brazilian farmers can use the dose $25 \mathrm{Mg} \mathrm{ha}^{-1}$ for improvement of physical and chemical properties in sandy and clay loam soil.

\section{Conclusions}

The biochar addition contributes to soil C sequestration. In addition, there was an improvement in the physical properties such as bulk density, and porosity for both for loamy and sandy soil. However, the water retention was different between soils, for the sandy soil the addition of biochar did not improve the water retention, but for loamy soil, biochar increased the water retention when applied at $25 \mathrm{Mg} \mathrm{ha}^{-1}$. The maximum dose of biochar altered the pore size distribution, increasing, especially, the mesoporosity and microporosity in clay loam soil and macroporosity in sandy soil.

These results show that biochar can improve soil management in the humid tropics, for example in response to shortages of water. It ought to be possible to recommend to farmers or other land use stakeholders that the biochar with another organic material easily decomposable should be added to a given type of soil with the aim of achieving the desired outcome, e.g., in terms of increase of water retention, the high biochar dose superior to $25 \mathrm{Mg} \mathrm{ha}^{-1}$ could be used in clay loam and sandy soil. However, studies are necessary to indicate which is the better dose superior to $25 \mathrm{Mg} \mathrm{ha}^{-1}$ for these soils and what is the best organic material that is easily decomposable to include with the biochar.

Author Contributions: S.d.J.D. was responsible by experimental conduction, wrote the manuscript and contributed to statistical analyze; B.G. contributed to the review and improvement of the paper. R.P.d.L. contributed to statistical analysis; C.E.P.C. contributed to the experimental design, experimental conduction, and review of the paper.

Funding: CNPq (process number 404150/2013-6).

Acknowledgments: This study was supported by CNPq (process number 404150/2013-6) and partially developed in University of Sao Paulo Brazil and in the Martin Luther University Halle (Saale), Germany and Fellowship was supported by Coordination for the Improvement of Higher Education Personnel (CAPES).

Conflicts of Interest: The authors declare no conflict of interest.

\section{References}

1. Glaser, B.; Haumaier, L.; Guggenberger, G.; Zech, W. The “Terra Preta" phenomenon: A model for sustainable agriculture in the humid tropics. Naturwissenschaften 2001, 88, 37-41. [CrossRef] [PubMed]

2. Glaser, B.; Lehmann, J.; Zech, W. Ameliorating physical and chemical properties of highly weathered soils in the tropics with charcoal-A review. Biol. Fertil. Soils 2002, 35, 219-230. [CrossRef]

3. Ajayi, A.E.; Horn, R. Biochar-induced changes in soil resilience: Effects of soil texture and biochar dosage. Pedosphere 2017, 27, 236-247. [CrossRef] 
4. Glaser, B.; Haumaier, L.; Guggenberger, G.; Zech, W. Black carbon in soils: The use of benzenecarboxylic acids as specific markers. Org. Geochem. 1998, 29, 811-819. [CrossRef]

5. Glaser, B.; Balashov, E.; Haumaier, L.; Guggenberger, G.; Zech, W. Black carbon in density fractions of anthropogenic soils of the Brazilian Amazon region. Org. Geochem. 2000, 31, 669-678. [CrossRef]

6. Liu, J.; Schulz, H.; Brandl, S.; Miehtke, H.; Huwe, B.; Glaser, B. Short-term effect of biochar and compost on soil fertility and water status of a Dystric Cambisol in NE Germany under field conditions. J. Plant Nutr. Soil Sci. 2012, 175, 698-707. [CrossRef]

7. Omondi, M.O.; Xia, X.; Nahayo, A.; Liu, X.; Korai, P.K.; Pan, G. Quantification of biochar effects on soil hydrological properties using meta-analysis of literature data. Geoderma 2016, 274, 28-34. [CrossRef]

8. Downie, A.; Crosky, A.; Munroe, P. Physical properties of biochar. In Biochar for Environmental Management: Science and Technology; Lehmann, J., Joseph, S., Eds.; Earthscan: London, UK, 2009; pp. 13-32.

9. Cheng, C.H.; Lehmann, J.; Thies, J.E.; Burton, S.D.; Engelhard, M.H. Oxidation of black carbon by biotic and abiotic processes. Org. Geochem. 2006, 37, 1477-1488. [CrossRef]

10. Piccolo, A.; Mbagwu, J.S.C. Effects of different organic waste amendments on soil microaggregates stability and molecular sizes of humic substances. Plant Soil 1990, 123, 27-37. [CrossRef]

11. Lehmann, J.; Gaunt, J.; Rondon, M. Bio-char sequestration in terrestrial ecosystems. A review. Mitig. Adapt. Strateg. Glob. Chang. 2006, 11, 403-427. [CrossRef]

12. Blanco-Canqui, H. Biochar and soil physical properties. Soil Sci. Soc. Am. J. 2017, 84, 687. [CrossRef]

13. Alghamdi, A.G. Biochar as a potential soil additive for improving soil physical properties-A review. Arab. J. Geosci 2018, 11, 776. [CrossRef]

14. Laird, D.A.; Fleming, P.; Davis, D.D.; Horton, R.; Wang, B.; Karlen, D.L. Impact of biochar amendments on the quality of a typical Midwestern agricultural soil. Geoderma 2010, 158, 443-449. [CrossRef]

15. Zhang, A.; Bian, R.; Pan, G.; Cui, L.; Hussain, Q.; Li, L.; Zheng, J.; Zheng, J.; Zhang, X.; Han, X.; et al. Effects of biochar amendment on soil quality, crop yield and greenhouse gas emission in a Chinese rice paddy: A field study of 2 consecutive rice growing cycles. F. Crop. Res. 2012, 127, 153-160. [CrossRef]

16. Novak, J.M.; Busscher, W.J.; Watts, D.W.; Amonette, J.E.; Ippolito, J.A.; Lima, I.M.; Gaskin, J.; Das, K.C.; Steiner, C.; Ahmedna, M.; et al. Biochars impact on soil-moisture storage in an ultisol and two aridisols. Soil Sci. 2012, 177, 310-320. [CrossRef]

17. International Biochar Initiative. Standardized Product Definition and Product Testing Guidelines for Biochar That is Used in Soil, International Biochar Initiative. 2015. Available online: http: / /www.biocharinternational.org/sites/defaut/files/IBI_Biochar_Standards_V1.1.pdf (accessed on 5 December 2018).

18. Chan, K.Y.; Bowman, A.; Oates, A. Oxidizable organic carbon fractions and soil quality changes in an oxic paleustaff under different pasture leys. Soil Sci. 2001, 166, 61-67. [CrossRef]

19. American Society for Testing and Materials. Standard Test Method for the Analysis of Wood Charcoal (ASTM D1762-84); ASTM International: West Conshohocken, PA, USA, 2007.

20. American Society for Testing and Materials. Test Method for Ash in the Analysis Sample of Coal and Coke from Coal; ASTM International: West Conshohocken, PA, USA, 2007.

21. Cerato, A.B.; Lutenegger, A.J. Determination of surface area of fine-grained soils by the ethylene glycol monoethyl ether (EGME) method. Geotech. Test. J. 2002, 25, 315-321. [CrossRef]

22. Watson, C.L.; Letey, J. Indices for characterizing soil-water repellency based upon contact angle-surface tension relationships. Soil Sci. Soc. Am. J. 1970, 34, 841-844. [CrossRef]

23. Letey, J.; Carrillo, M.L.K.; Pang, X.P. Approaches to characterize the degree of water repellency. J. Hydrol. 2000, 231-232, 61-65. [CrossRef]

24. Van Raij, B.; Andrade, J.C.; Cantarella, H.; Quaggio, J.A. Análise Química para Avaliação da Fertilidade de Solos Tropicais; Campinas Instituto Agronômico: Campinas, Brazil, 2001; 285p.

25. LECO Corporation CN-2000. Available online: http://www.labwrench.com/?equipment.view/ equipmentNo/14102/LECO-Corporation/CN-2000/ (accessed on 3 December 2018).

26. Blake, G.R.; Hartge, K.H. Bulk density. In Methods of Soil Analysis, Part 1-Physical and Mineralogical Methods, 2nd ed.; Klute, A., Ed.; Agronomy Monograph 9; American Society of Agronomy-Soil Science Society of America: Madison, WI, USA, 1986; pp. 363-382.

27. Gee, G.W.; Bauder, J.W. Particle-size analysis. In Methods of Soil Analysis, Part 1—Physical and Mineralogical Methods, 2nd ed.; Klute, A., Ed.; Agronomy Series 9; American Society of Agronomy-Soil Science Society of America: Madison, WI, USA, 2002; pp. 383-411. 
28. Flint, L.E.; Flint, A.L. Porosity. In Methods in Soil Analysis, Part 4-Physical Methods; Dane, J.H., Topp, G.C., Eds.; Soil Science Society of America: Madison, WI, USA, 2002.

29. Koorevaar, P.; Menelik, G.; Kirksen, C. Elements of Soil Physics: Developments in Soil Science; Elsevier: Amsterdam, The Netherlands, 1983; Volume 13, 228p.

30. Klute, A.; Klute, A.; Dirksen, C. Hydraulic Conductivity and Diffusivity: Laboratory Methods 9; ASA: Madison, WI, USA, 1986.

31. Van-Genuchten, M.T. A Closed-form equation for predicting the hydraulic conductivity of unsaturated Soils. Soil. Sci. Soc. Am. 1980, 44, 892-898. [CrossRef]

32. RStudio Team. RStudio: Integrated Development for R; RStudio, Inc.: Boston, MA, USA, 2015; Available online: http:/ / www.rstudio.com/ (accessed on 2 December 2018).

33. Conz, R.F.; Abbruzzini, T.F.; Andrade, C.A.; Milori, D.M.B.P.; Cerri, C.E.P. Effect of pyrolysis temperature and feedstock type on agricultural properties and stability of biochars. Agricult. Sci. 2017, 8, 914-933.

34. Hammes, K.; Torn, M.S.; Lapenas, A.G.; Schmidt, M.W.I. Centennial black carbon turnover observed in a Russian steppe soil. Biogeosci. 2008, 5, 1339-1350. [CrossRef]

35. Weber, J.; Karczewska, A.; Drozd, J.; Licznar, M.; Licznar, S.; Jamroz, E.; Kocowicz, A. Agricultural and ecological aspects of a sandy soil as affected by the application of municipal solid waste composts. Soil Biol. Biochem. 2007, 39, 1294-1302. [CrossRef]

36. Zimmerman, J.K.; Pulliam, W.M.; Lodge, D.J.; Quiñones-Orfila, V.; Fetcher, N.; Guzmán-Grajales, S. Nitrogen immobilization by decomposing woody debris and the recovery of tropical wet forest from hurricane damage. Oikos 1995, 72, 314. [CrossRef]

37. Atkinson, C.J.; Fitzgerald, J.D.; Hipps, N.A. Potential mechanisms for achieving agricultural benefits from biochar application to temperate soils: A review. Plant Soil 2010, 337, 1-18. [CrossRef]

38. Arvidsson, J. Nutrient uptake and growth of barley as affected by soil compaction. Plant Soil 1999, 208, 9-19. [CrossRef]

39. Usowicz, B.; Lipiec, J.; ukowski, M.; Marczewski, W.; Usowicz, J. The effect of biochar application on thermal properties and albedo of loess soil under grassland and fallow. Soil Tillage Res. 2016, 164, 45-51. [CrossRef]

40. Bruun, E.W.; Petersen, C.T.; Hansen, E.; Holm, J.K.; Hauggaard-Nielsen, H. Biochar amendment to coarse sandy subsoil improves root growth and increases water retention. Soil Use Manag. 2014, 30, 109-118. [CrossRef]

41. Devereux, R.C.; Sturrock, C.J.; Mooney, S.J. The effects of biochar on soil physical properties and winter wheat growth. Earth Environ. Sci. Trans. R. Soc. Edinburgh 2013, 103, 13-18. [CrossRef]

42. Githinji, L. Effect of biochar application rate on soil physical and hydraulic properties of a sandy loam. Arch. Agron. Soil Sci. 2014, 60, 457-470. [CrossRef]

43. Simpson, T.L.; Volcani, B.E. Silicon and Siliceous Structures in Biological Systems; Springer: New York, NY, USA, 1981.

44. Pandis, C.; Spanoudaki, A.; Kyritsis, A.; Pissis, P.; Hernández, J.C.R.; Gõmez Ribelles, J.L.; Monleõn Pradas, M. Water sorption characteristics of poly(2-hydroxyethyl acrylate)/silica nanocomposite hydrogels. J. Polym. Sci. Part B Polym. Phys. 2011, 49, 657-668. [CrossRef]

45. Kinney, T.J.; Masiello, C.A.; Dugan, B.; Hockaday, W.C.; Dean, M.R.; Zygourakis, K.; Barnes, R.T. Hydrologic properties of biochars produced at different temperatures. Biomass Bioenergy 2012, 41, 34-43. [CrossRef]

46. Ojeda, G.; Mattana, S.; Àvila, A.; Alcañiz, J.M.; Volkmann, M.; Bachmann, J. Are soil-water functions affected by biochar application? Geoderma 2015, 249-250, 1-11. [CrossRef]

47. Mukherjee, A.; Lal, R. Biochar impacts on soil physical properties and greenhouse gas emissions. Agronomy 2013, 3, 313-339. [CrossRef]

48. Jeffery, S.; Verheijen, F.G.A.; van der Velde, M.; Bastos, A.C. A quantitative review of the effects of biochar application to soils on crop productivity using meta-analysis. Agric. Ecosyst. Environ. 2011, 144, 175-187. [CrossRef]

49. Peake, L.R.; Reid, B.J.; Tang, X. Quantifying the influence of biochar on the physical and hydrological properties of dissimilar soils. Geoderma 2014, 235-236, 182-190. [CrossRef]

50. Christensen, B.T. Wheat and barley straw decomposition under field conditions: Effect of soil type and plant cover on weight loss, nitrogen and potassium content. Soil Biol. Biochem. 1985, 17, 691-697. [CrossRef]

51. Andrenelli, M.C.; Maienza, A.; Genesio, L.; Miglietta, F.; Pellegrini, S.; Vaccari, F.P.; Vignozzi, N. Field application of pelletized biochar: Short term effect on the hydrological properties of a silty clay loam soil. Agricult. Water Manag. 2016, 163, 190-196. [CrossRef] 
52. Gaskin, J.W.; Speir, R.A.; Harris, K.R.; Lee, R.D.; Morris, L.M.; Das, K.C. Effect of two types of pyrolysis chars on corn yield, soil nutrient status, and soil C in loamy sand soil of the southeastern United States. In Proceedings of the ASA-CSSA-SSSA International annual Meetings, Madison, WI, USA, 4-18 November 2007.

53. Salinas, J.; García, I.; Del Moral, F.; Simón, M. Use of marble sludge and biochar to improve soil water retention capacity. Spanish J. Soil Sci. 2018, 8, 121-129. [CrossRef]

54. Baronti, S.; Vaccari, F.P.; Miglietta, F.; Calzolari, C.; Lugato, E.; Orlandini, S.; Pini, R.; Zulian, C.; Genesio, L. Impact of biochar application on plant water relations in Vitis vinifera (L.). Eur. J. Agron. 2014, 53, $38-44$. [CrossRef]

55. Skin, J.W.; Speir, A.; Morris, L.M.; Ogden, L.; Harris, K.; Lee, D.; Das, K.C. Potential for pyrolysis char to affect soil moisture and nutrient retention status of a loamy sand soil. In Proceedings of the 2007 Georgia Water Resources Conference, Athens, Georgia, 27-29 March 2007.

56. Liu, Z.; Dugan, B.; Masiello, C.A.; Gonnermann, H.M. Biochar particle size, shape, and porosity act together to influence soil water properties. PLoS ONE 2017, 12, e0179079. [CrossRef] [PubMed]

57. Major, J.; Rondon, M.; Molina, D.; Riha, S.J.; Lehmann, J. Maize yield and nutrition during 4 years after biochar application to a Colombian savanna oxisol. Plant Soil 2010, 333, 117-128. [CrossRef]

58. Conte, P.; Hanke, U.M.; Marsala, V.; Cimoò, G.; Alonzo, G.; Glaser, B. Mechanisms of water interaction with pore systems of hydrochar and pyrochar from poplar forestry waste. J. Agric. Food Chem. 2014, 62, 4917-4923. [CrossRef]

59. Castellini, M.; Giglio, L.; Niedda, M.; Palumbo, A.D.; Ventrella, D. Impact of biochar addition on the physical and hydraulic properties of a clay soil. Soil Tillage Res. 2015, 154, 1-13. [CrossRef]

60. Brewer, C.E.; Chuang, V.J.; Masiello, C.A.; Gonnermann, H.; Gao, X.; Dugan, B.; Driver, L.E.; Panzacchi, P.; Zygourakis, K.; Davies, C.A. New approaches to measuring biochar density and porosity. Biomass Bioenergy 2014, 66, 176-185. [CrossRef]

61. Tryon, E.H. Effect of charcoal on certain physical, chemical, and biological properties of forest soils. Ecol. Monogr. 1948, 18, 81-115. [CrossRef]

(C) 2019 by the authors. Licensee MDPI, Basel, Switzerland. This article is an open access article distributed under the terms and conditions of the Creative Commons Attribution (CC BY) license (http:/ / creativecommons.org/licenses/by/4.0/). 